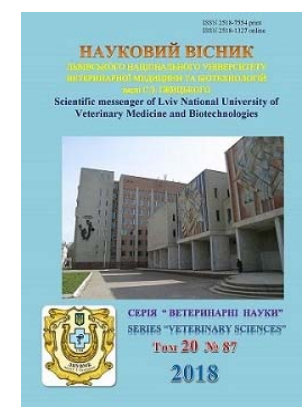

\author{
Науковий вісник Дьвівського національного університету \\ ветеринарної медицини та біотехнологій імені С.З. Гжицького
}

\author{
Scientific Messenger of Lviv National University \\ of Veterinary Medicine and Biotechnologies
}

\title{
Adaptation of the status of non-specific resistance of the ducks organism in stress conditions inclusion in the ration of probiotical additives
}

\author{
V.G. Stoyanovskyy, A.O. Krogh, I.A. Kolomiiets \\ Stepan Gzhytskyi National University of Veterinary Medicine and Biotechnologies Lviv, Ukraine
}

Article info

Received 01.02.2018

Received in revised form 08.03 .2018

Accepted 14.03.2018

Stepan Gzhytskyi National University of Veterinary Medicine and Biotechnologies,

Pekarska str., 50, Lviv,

79010, Ukraine.

Tel.: +38-067-112-41-45

E-mail: kolomieciryna@gmail.com
Stoyanovskyy, V.G., Krogh, A.O., \& Kolomiiets, I.A. (2018). Adaptation of the status of non-specific resistance of the ducks organism in stress conditions inclusion in the ration of probiotical additives. Scientific Messenger of Lviv National University of Veterinary Medicine and Biotechnologies. 20(87), 32-37. doi: 10.15421/nvlvet8706

The article deals with the question of adaptation of the ducks organism during industrial cultivation for action of stress. The complex of successive stage reactions, caused by the functioning of stress-implementing systems, arise in the body of the poultry in response to the influence of destabilizing factors and aimed at neutralizing these factors, preservation of homeostasis. Increasing the influence of technological stress factors leads to a decrease in the immune status of the duck organism. The study of the effectiveness of incorporating into the diet ducks harmless feed additives, which contributes to the normalization of the course of adaptive-compensatory reactions in their body during the critical periods of postnatal ontogenesis and can serve as anti-stress prevention in conditions of industrial growth of this species of poultry remains relevant. The purpose of the work is to find out the implementation of an adaptation syndrome in the system of indices of non-specific resistance of the body of ducks when it is included in the diet of the biologically active feed supplement "Primix Bionorm K» and supplements «Biovir». The experiment was conducted on clinically healthy young ducks of the Pekin breed of egg production line. In the 270-day age, all three groups of ducks were modeled experimental technological stress in the form of prolonged transport. From 240 to 270 days of age, ducks additionally fed the additive "Primix Bionorm K» and was pouring with water an additive "Biovir». The material for research was blood, which was taken until morning feeding after slaughter on 240 days of life (to stress), 270 days of life (stage of anxiety), at 273 and 285 days (stages of resistance). Adaptation of the state of non-specific resistance of the duck of the control group to the control group under conditions of stress in the anxiety stage is characterized by an increase of $17.3 \%(P<0.05)$ of the value of the bactericidal activity of the blood serum, a decrease of $8.5 \%$ of the value of lysozyme activity of the blood serum, by $9.3 \%$ of phagocytic activity against the background of growth on $8.7 \%$ of the number of circulating immune complexes compared to 240-day-old poultry. At the stage of resistance there is a decrease in the amount of blood serum bactericidal activity by $17.3 \%(P<0.05)$, an increase in the activity of lysozyme in blood serum by $8.5 \%$, and the number of immune complexes by $20.7 \%(P<0.05)$, with the stabilization of the studied parameters at the later stages of the development of a stress reaction. In these periods, a decrease in the body weight of control group ducks was set at $5.7-6.8 \%$. Feeding of the additive "Primix Bionorm K» during the period of the implementation of the stress syndrome has a positive effect on the indices of the cellular and humoral level of nonspecific resistance in the form of an increase in the amount of bactericidal activity of the serum on 38.2\% $(P<0.05)$, an increase in the activity of phagocytosis by $15.1 \%(P<0.05)$, phagocytic index - by 36.1\% $(P<0.05)$ with a decrease in the number of circulating immune complexes by $15.5 \%$. The presentation of the additive «Biovir» causes an increase in the level of bactericidal and lysozyme activity of the blood serum on $47.3 \%(P<0.01)$ and $18.7 \%(P<0.05)$. The use of additives can reduce the negative effect of transport stress in the duck body, increase nutrient uptake, as indicated by an increase in the body weight of experimental birds in the average by $7.1-10.5 \%(P<0.05)$ during the development of the adaptive syndrome.

Key words: adaptation, non-specific resistance, productivity, stress, transportation, ducks, probiotical additives. 


\title{
Адаптація стану неспецифічної резистентності організму качок в умовах стресу при включенні в раціон пробіотичних добавок
}

\author{
В.Г. Стояновський, А.О. Крог, І.А. Коломієць
}

\author{
Львівський національний університет ветеринарної медицини та біотехнологій імені С.3. Гжиџького, \\ м. Львів, Україна
}

У статті висвітлено питання адаптації організму качок промислового вирощування за дї стресу. Комплекс послідовних стадійних реакцій, обумовлених функціонуванням стрес-реалізуючих систем, виникають в організмі птиці у відповідь на вплив дестабілізуючих факторів і спрямовані на нейтралізацію цих чинників, збереження гомеостазу. Вплив технологічних стресових факторів призводить до зниження імунного статусу організму качок. Актуальним залишається вивчення ефективності включення в раціон качок нешкідливих кормових добавок, щзо сприяє нормалізації перебігу адаптаційно-компенсаторних реакиій в їхньому організмі у критичні періоди постнатального онтогенезу і може слугувати антистресовою профілактикою в умовах промислового вирошування цьього виду птиці. Мета роботи - з'ясувати реалізацію адаптаційного синдрому у системі показників неспецифічної резистентності організму качок при включенні в рачіон біологічно активної кормової добавки «Праймікс Біонорм-К» та добавки «Біовір». Дослід проведено на клінічно здоровому молодняку качок пекінської породи яєчного напрямку продуктивності. У 270-добовому вічі качкам було змодельовано експериментальний технологічний стрес у вигляді тривалого транспортування. 3 240- до 270-добового віку птиці додатково згодовували добавку «Праймікс Біонорм-К» та випоювали з водою добавку «Біовір». Матеріалом для досліджень слугувала кров, яку відбирали до ранкової годівлі після забою на 240 добу життя (до дії стресу), 270 добу життя (стадія тривоги), на 273 і 285 добу (етапи стадії резистентності). Адаптація стану неспецифічної резистентності організму качок контрольної групи в умовах стресу на стадї тривоги характеризується підвищенням на 17,3\% (P < 0,05) величини бактерицидної активності сироватки крові, зниженням на 8,5\% величини лізочимної активності сироватки крові, на 9,3\% фагочитарної активності на тлі зростання на 8,7\% кількості ииркулюючих імунних комплексів порівняно з 240-добовою птицею. На стадї̈ резистентності спостерігається вірогідне зниження величини бактерицидної активності сироватки крові на 17,3\%, підвищення активності лізоциму у сироватиі крові на 8,5\% та кількості імунних комплексів на 20,7\% зі стабілізацією досліджуваних показників на пізніх етапах розвитку стресової реакції. В дані періоди установлено зниження маси тіла качок контрольної групи на 5,7-6,8\%. Згодовування добавки «Праймікс Біонорм К» у період реалізаиї стресового синдрому чинить позитивний вплив на показники клітинної і гуморальної ланки неспецифічної резистентності у вигляді зростання величини бактерицидної активності сироватки крові на 38,2\% (P<0,05), підвищення активності фагоцитозу на 15,1\% $(P<0,05)$, фагоцитарного індексу - на $36,1 \%(P<$ 0,05) зі зниженням кількості цииркулюючих імунних комплексів на 15,5\%. Випоювання добавки «Біовір» зумовлює підвищення величини бактерицидної та лізоцимної активності сироватки крові на 47,3\% (P<0,01) та 18,7\% (P< 0,05). Застосування добавок дозволяе знизити негативну дію транспортного стресу в організмі качок, підвищити засвоєння поживних речовин корму, на щзо вказує збільшення маси тіла птиці дослідних груп в середньому на 7,1-10,5\% (P<0,05) впродовж розвитку адаптаційного синдрому. бавки.

Ключові слова: адаптація, неспецицфічна резистентність, продуктивність, стрес, транспортування, качки, пробіотичні до-

\section{Вступ}

Розведення качок яєчного напрямку продуктивності включає ряд особливостей, які пов'язані з функціонуванням їхнього організму і впливом на птицю різних зовнішніх факторів, що актуалізує вивчення проблеми адаптаційного потенціалу (Martinez et al., 2017). За даними (Bolotnikov et al., 1999; Infante et al., 2017), динамічність процесів адаптації та їх реалізація в необхідному діапазоні за дії стресу залежить від рівня імунобіологічної реактивності організму птиці. Вплив таких технологічних стресових факторів, як перегрупування, висока щільність посадки, порушення мікроклімату в пташнику, зміна годівлі призводить до зниження імунного статусу організму молодняку качок промислового вирощування (Chen et al., 2018). Одними 3 найбільш поширених стресових факторів в умовах промислового птахівництва (Voronina, 2003; Stojanovskij et al., 2012) вважають транспортний стрес, що призводить до зниження яєчної і м'ясної продуктивності. Комплекс послідовних стадійних реакцій, обумовлених функціонуванням стресреалізуючих систем, виникає в організмі птиці у відповідь на вплив дестабілізуючих факторів і спрямований на нейтралізацію цих чинників, збереження гомеостазу (Stojanovskij et al., 2018). В літературі є окремі розрізнені та неповні й суперечливі дані стосовно способів нівелювання патогенетичних механізмів порушення функціонального стану організму качок у критичні періоди постнатального онтогенезу за дії стресу, які обмежені певними віковими групами (Olubodun et al., 2015). Актуальним залишається вивчення ефективності включення в раціон качок біологічно сумісних, нешкідливих кормових добавок, що сприяє нормалізації перебігу адаптаційнокомпенсаторних реакцій в їхньому організмі у критичні періоди постнатального онтогенезу і може слугувати антистресовою профілактикою в умовах промислового вирощування цього виду птиці (Pavlova, 2015; Kapustian et al., 2018). Мета роботи - з'ясувати реалізацію адаптаційного синдрому у системі показників неспецифічної резистентності організму качок при включенні в раціон біологічно активної кормової добавки (БАКД) «Праймікс Біонорм-К» та добавки «Біовір».

\section{Матеріал та методи досліджень}

Усі маніпуляції з качками проводили з дотриманням вимог «Європейської конвенції про захист хребетних тварин, які використовуються для експериментальних і наукових цілей» (Страсбург, 1986), ухвали Першого національного конгресу з біоетики (Київ, 2001) - «Загальні етичні принципи експериментів на 
тваринах» та 3 дотриманням принципів гуманності, викладеними у директиві Європейської Спільноти. Дослід проведено в умовах ДП ДГ «Миклашівське» с. Миклашів Пустомитівського району Львівської області на клінічно здоровому молодняку качок пекінської породи яєчного напрямку продуктивності. У 240-добовому віці було сформовано три групи птиці - контрольна (К) і дві дослідні $\left(Д_{1}, Д_{2}\right)$ по 100 голів в кожній групі, підібраних за принципом аналогів. Годівля птиці проводилася відповідно до періоду вирощування. 3 240- до 270-добового віку качкам Д групи додатково згодовували БАКД «Праймікс Біонорм-К» (симбіотик на основі живих ліофілізованих біфідо- і лактобактерій з активністю не менше $1 \times 10^{9}$ КУО/1г, лактулоза, целюлоза мікрокристалічна, натрію глутамат) 3 розрахунку 0,02 г/кг маси тіла на добу; Д2 групі птиці випоювали з водою добавку «Біовір» (комплекс активованих низькомолекулярних пептидів клітинної стінки біфідо- і лактобактерій, продуктів їх метаболізму (молочна, оцтова кислоти, лізоцим, реуретрин, плантарицин, лактоцидин, лактолін, ацидофілін) у загальній кількості 700 г/кг, бурштинова кислота у загальній кількості 300 г/кг) 3 розрахунку 0,0125мл/кг маси тіла на добу згідно з інструкцією виробника (біотехнологічна компанія «Аріадна» м. Одеса). У 270-добовому віці качкам усіх трьох груп було змодельовано експериментальний технологічний стрес у вигляді тривалого транспортування. Матеріалом для досліджень слугувала кров, яку відбирали до ранкової годівлі після забою на 240 добу життя (до дії стресу), 270 добу життя (стадія тривоги), на 273 і 285 добу (етапи стадії резистентності) по 5 особин в кожному періоді. Зважування птиці проводили у вищевказані періоди. У гепаринізованій крові визначали фагоцитарну активність псевдоеозинофілів (ФА) та фагоцитарний індекс (ФI) - за методом В.Е. Чумаченка; у сироватці крові лізоцимну активність (ЛАСК) - фотоелектроколориметричним методом за В.Г. Дорофейчуком, бактерицидну активність (БАСК) - за методом О.В. Смирнової, Т.А. Кузьміної, рівень циркулюючих імунних комплексів (ЦІК) - за методом преципітації імунних комплексів високомолекулярним поліетиленгліколем (Vlizlo et al., 2012). Ступінь вірогідності різниці (Р) між досліджуваними показниками качок Д, Д 2 групи порівняно з К групою проводили в програмі Statystika для Windows XP $з$ використанням критерію $\mathrm{t}$ Стьюдента. Результати середніх значень вважали статистично вірогідними при $\mathrm{P}<0,05-*, \mathrm{P}<0,01-* *$, $\mathrm{P}<0,001-* * *$.

\section{Результати та їх обговорення}

При дослідженні загальних фізіологічних показників в умовах транспортування качок відмічалося прискорення дихання, скупчування птиці К і Д 1 , Д групи, проте не встановлено відхилень безумовно рефлекторної та умовно рефлекторної діяльності птиця на дію зовнішніх подразників реагувала адекватно. Результати дослідження показників, що характеризують стан гуморальної і клітинної ланки імунного статусу організму качок за дії стресу на тлі згодовування добавок наведені у таблиці 1. Встановлено, що на 240 добу життя (початок експерименту) величина БАСК у качок $\mathrm{K}$ і Д 1 , Д 2 групи складала в середньому $60,45 \pm 4,90 \%$, величина ЛАСК $-36,50 \pm$ 4,50\%, що перебувало у межах фізіологічних величин для даного віку птиці.

\section{Таблиця 1}

Стан гуморальної і клітинної ланки імунного статусу організму качок за дії стресу на тлі згодовування добавок $(\mathrm{M} \pm \mathrm{m}, \mathrm{n}=5)$

\begin{tabular}{|c|c|c|c|c|c|c|}
\hline $\begin{array}{l}\text { Вік, } \\
\text { доба }\end{array}$ & Групи & БАСК, \% & ЛАСК, \% & $\Phi A, \%$ & ФІ, м.т./псевд. & ЦІК, Од. в 100 мл \\
\hline \multirow{3}{*}{240} & $\mathrm{~K}$ & $60,45 \pm 4,90$ & $36,50 \pm 4,50$ & $32,00 \pm 2,90$ & $9,25 \pm 1,30$ & $19,51 \pm 2,50$ \\
\hline & $Д_{1}$ & $62,93 \pm 6,40$ & $37,73 \pm 3,63$ & $30,87 \pm 2,37$ & $8,90 \pm 0,80$ & $20,00 \pm 2,42$ \\
\hline & $\mathrm{Д}_{2}$ & $61,57 \pm 5,15$ & $35,03 \pm 4,80$ & $31,83 \pm 3,70$ & $8,50 \pm 1,45$ & $21,33 \pm 2,20$ \\
\hline \multirow{3}{*}{270} & $\mathrm{~K}$ & $70,91 \pm 4,18$ & $33,40 \pm 3,90$ & $29,02 \pm 2,59$ & $8,90 \pm 0,74$ & $21,22 \pm 2,34$ \\
\hline & $Д_{1}$ & $81,97 \pm 4,02 *$ & $45,28 \pm 4,01^{*}$ & $33,35 \pm 2,11$ & $8,40 \pm 1,23$ & $19,13 \pm 2,90$ \\
\hline & $\check{Д}_{2}$ & $76,08 \pm 4,45$ & $34,11 \pm 5,52$ & $36,20 \pm 2,15^{*}$ & $9,51 \pm 0,87$ & $20,65 \pm 2,40$ \\
\hline \multirow{3}{*}{273} & $\mathrm{~K}$ & $50,15 \pm 5,03$ & $39,62 \pm 3,30$ & $31,12 \pm 2,03$ & $8,72 \pm 0,81$ & $23,55 \pm 2,01$ \\
\hline & $Д_{1}$ & $69,32 \pm 4,40^{* *}$ & $41,50 \pm 4,80$ & $35,83 \pm 1,60^{*}$ & $11,87 \pm 0,95^{* *}$ & $19,90 \pm 2,12 *$ \\
\hline & $\mathrm{Д}_{2}$ & $73,85 \pm 5,92 * *$ & $47,02 \pm 3,78^{*}$ & $32,87 \pm 2,37$ & $9,90 \pm 0,90$ & $22,78 \pm 1,90$ \\
\hline \multirow{3}{*}{285} & $\mathrm{~K}$ & $53,84 \pm 4,10$ & $41,45 \pm 4,01$ & $30,25 \pm 2,90$ & $8,57 \pm 1,12$ & $20,10 \pm 2,40$ \\
\hline & $Д_{1}$ & $52,30 \pm 5,64$ & $57,12 \pm 4,10^{* *}$ & $31,20 \pm 3,45$ & $10,22 \pm 0,88$ & $19,80 \pm 2,50$ \\
\hline & $Д_{2}$ & $60,85 \pm 4,11$ & $61,05 \pm 5,09 * *$ & $32,75 \pm 3,52$ & $9,95 \pm 0,91$ & $19,51 \pm 2,75$ \\
\hline
\end{tabular}

Стан клітинної ланки імунного статусу організму качок всіх груп у цьому віковому періоді характеризувався величиною ФА у значенні $30,87 \pm 2,37-$ $32,00 \pm 3,90 \%$. Що стосується показника ФІ, то варто відмітити, що у качок К групи його значення складало 9,25 $\pm 1,30$ м.т./псевд., а в Д, Д 2 групи виявилося нижчим і становило 8,90 $\pm 0,80-8,50 \pm 1,45$ м.т./псевд. За рахунок нижчої інтенсивності фагоцитозу кількість ЦІК у качок Д $1, Д_{2}$ групи була дещо вищою і складала
$20,00 \pm 2,42$ та $21,33 \pm 2,20$ Од. в 100 мл порівняно 3 качками К групи.

Як відомо, імунна система тварин та птиці найбільш чутлива до різного роду стресів, а в результаті іiі розбалансування знижується природна резистентність до різних захворювань (Stojanovskij et al., 2012; Kolomiec, 2013; Hariv and Gutyj, 2017; Gutyj et al., 2017; Khariv et al., 2017). На 270 добу життя у качок К групи виявляли вірогідне підвищення на 17,3\% вели- 
чини БАСК, зниження на 8,5\% величини ЛАСК, на 9,3\% ФА на фоні зростання на 8,7\% кількості ЦІК, порівняно з 240-добовою птицею, що могло виступати ознакою розвитку стресової реакції на їх організм. Порівняно з качками, які отримували БАКД «Праймікс Біонорм-К» та добавку «Біовір», у птиці К групи показники, які характеризують стан гуморальної та клітинної ланки неспецифічної резистентності у різні періоди дії стресу (транспортування) залишалися нижчими. На 270 добу життя у качок Д групи виявлено підвищення величини БАСК на $15,6 \%$ (P $<0,05)$, ЛАСК - на 35,6\% $(\mathrm{P}<0,05)$. Подібний характер динаміки може бути обумовлений рядом факторів, насамперед тим, що БАСК і ЛАСК належить значна роль у захисті організму від інфекцій, а їхня висока активність спрямована на підтримку стійкості організму качок до несприятливих факторів навколишнього середовища (Vishhur et al., 2010). Підвищення активності досліджуваних величин у качок Д г групи могло відбуватися за рахунок збільшення кількості лакто- та біфідобактерій у кишечнику, імуностимулююча функція яких реалізується за рахунок мурамілдипептидів клітинних стінок, що активують утворення інтерферону, цитокінів, комплементу (Mohammed et al., 2018). Підвищення кількості лізоциму в сироватці крові могло бути обумовлено однією 3 функцій біфідобактерій, оскільки вони містять у складі клітинної мембрани до 20\% мурамілдипептиду, який є антигенним подразником для виділення мурамілпептидази (Wójcik et al., 2017). Стан клітинної ланки імунітету качок 270-добового віку не характеризувався вірогідними відмінностями, хоча кількість ЦІК була дещо нижчою порівняно з контролем і становила 19,13 $\pm 2,90$ Од. в 100 мл. На 270 добу життя у качок Д групи величина ЛАСК і БАСК перебували у межах контролю, проте стан клітинної ланки неспецифічної резистентності характеризувався підвищенням величини ФА на $24,8 \%(\mathrm{P}<0,05)$, що вказувало на позитивний вплив випоювання добавки «Біовір». Отримані результати зумовлені основними властивостями пептидоглікану, оскільки його розщеплення призводить до утворення глікопептидів, що володіють ад’ювантною дією, найбільш важливою $з$ яких $є$ плейотропна імуномодулююча дія, тобто стимуляції природних захисних реакцій організму, а також клітин лімфоцитарного ряду (Wójcik et al., 2017). В качок обох дослідних груп спостерігали тенденцію до зниження кількості ЦІК відносно контролю, проте вірогідних міжгрупових різниць не було виявлено.

Адаптація стану неспецифічної резистентності організму качок в умовах стресу на 273 добу життя характеризувалася такими ознаками: величина БАСК вірогідно знижувалася на 17,3\%, величина ЛАСК підвищувалася на 8,5\% на тлі зниження на 5,7\% показника ФІ порівняно 3 240-добовою птицею. В цей період кількість ЦІК була вищою на 20,7\% (Р < 0,05). Отримані числові значення на тлі зниженої величини БАСК у сироватці крові качок К групи могли бути наслідком дії стресу і виступали ознакою зниження імунологічної адаптації їх організму. На це вказує підвищення кількості ЦІК, що призводить до вираженого імунного дисбалансу, який може бути наслідком утворення комплексу з перевагою антигену, підвищення проникливості судинної стінки, тривалої циркуляції комплексів (Gaevska, 2000). У качок Д групи виявлено підвищення показників гуморальної і клітинної ланки імунного статусу їхнього організму за дії стресу у вигляді зростання величини БАСК на $38,2 \%$ (Р < 0,01), тенденції до зростання ЛАСК, підвищення ФА на $15,1 \%(\mathrm{P}<0,05)$, ФІ на 36,1\% $(\mathrm{P}<0,01)$ зі зниженням кількості ЦІК на $15,5 \%(\mathrm{P}<0,05)$, що було ознакою позитивного впливу згодовування БАКД «Праймікс Біонорм К» у період реалізації стресового синдрому, а також вказувало на пролонговану адаптогенну дію добавки в організмі птиці. Дещо іншими величинами характеризувався стан неспецифічної резистентності організму качок Д2 групи на 273 добу життя. У цей період виявлено підвищення величини БАСК на 47,3\% ( $<<0,01)$ та ЛАСК на $18,7 \%(\mathrm{P}<0,05)$ порівняно $3 \mathrm{~K}$ групою птиці, що було вищим відносно птиці Д 1 групи. Відсутність вірогідних змін у показниках клітинної ланки резистентності організму качок Д2 групи на 273 добу життя, за винятком деякого підвищення показника ФІ, вказував на незначний вплив добавки «Біовір» на здатність клітин крові до фагоцитозу.

Реалізація стресового синдрому на 285 добу життя качок К групи проходила у вигляді зниження величини БАСК на 10,9\%, підвищення величини ЛАСК на 13,6\%, зниження ФА і ФІ на 7,3\% та незначного зростання кількості ЦІК відносно качок 240-добового віку, що вказувало на стабілізацію стану неспецифічної резистентності їх організму на пізніх етапах розвитку стресової реакції. У цей період в качок Д 1 і Д 2 групи встановлено підвищення величини ЛАСК на 37,8 та 47,3\% (P $<0,01)$. Як відомо, ферментативна активність лізоциму обумовлена руйнуванням зв'язку між $\mathrm{N}$ ацетилмураміновою кислотою та $\mathrm{N}$-ацетилглюкозаміном у мукополісахаридах (Chen et al., 2018). Утворені глюкопептиди характеризуються ад'ювантною активністю (стимулюють синтез антитіл, підвищують цитотоксичну активність, індукують гіперчутливість сповільненого типу), тому підвищення величини ЛАСК може вказувати на зростання захисних механізмів організму качок дослідних груп в період розвитку стресової реакції. Дещо вищими залишалися величини БАСК, ФА, показник ФІ на фоні зниження кількості ЦІК в качок Д 1 і Д2 групи, проте відсутність вірогідних змін свідчили про незначний вплив добавок на клітинні фактори природної резистентності.

Динаміка маси тіла качок за дії стресу на тлі згодовування добавок наведена у таблиці 2. Встановлено, що на 270 добу життя у період розвитку стадії тривоги маса тіла качок $\mathrm{K}$ та Д 1 і Д 2 груп суттєво не відрізнялася від числових значення вихідного періоду експерименту та між собою. Проте у період розвитку адаптаційного синдрому (273 доба життя) виявляли зменшення маси тіла качок К групи на 6,8\% порівняно $з$ 240-добовою птицею. Очевидно, це пов'язано 3 тим, що дія стресу у вигляді транспортування викликала додаткову витрату енергетичних i поживних речовин їхнього організму. У качок Д 1 і Д 2 групи цей показник був вищим відповідно на 8,1 і 10,5\% (P < $0,05)$. 
Таблиця 2

Динаміка маси тіла качок за дії стресу на тлі згодовування добавок, г $(\mathrm{M} \pm \mathrm{m}, \mathrm{n}=10)$

\begin{tabular}{|c|c|c|c|c|}
\hline Вік, доба & 240 & 270 & 273 & 285 \\
\hline $\mathrm{K}$ & $2486,7 \pm 44,23$ & $2557,7 \pm 42,23$ & $2316,0 \pm 46,24$ & $2344,5 \pm 51,45$ \\
\hline$д_{1}$ & $2340,4 \pm 44,12$ & $2440,8 \pm 49,31$ & $2505,0 \pm 45,50 *$ & $2585,0 \pm 56,70^{*}$ \\
\hline Д$_{2}$ & $2500,6 \pm 53,70$ & $2540,5 \pm 53,20$ & $2560,0 \pm 54,20 *$ & $2510,0 \pm 52,20 *$ \\
\hline
\end{tabular}

На 285 добу життя маса тіла качок К групи була нижчою на 5,7\% порівняно з 240-добовою птицею. У качок Д 1 і Д групи цей показник був вищим відповідно на 10,2 і 7,1\% (P <0,05), що свідчило про інтенсивність метаболізму і засвоюваність поживних речовин корму за умови згодовування БАКД «Праймікс Біонорм К» та випоювання добавки «Біовір».

\section{Висновки}

Адаптація стану неспецифічної резистентності організму качок К групи в умовах стресу на стадії тривоги характеризується підвищенням на 17,3\% $(\mathrm{P}<0,05)$ величини БАСК, зниженням на $8,5 \%$ величини ЛАСК, на 9,3\% ФА на тлі зростання на 8,7\% кількості ЦІК порівняно 3 240-добовою птицею. На стадії резистентності спостерігається вірогідне зниження величини БАСК на 17,3\%, підвищення величини ЛАСК на 8,5\% та кількості ЦІК на 20,7\% (Р < 0,05) зі стабілізацією досліджуваних показників на пізніх етапах розвитку стресової реакції на тлі зниження маси тіла на 5,7-6,8\%. Згодовування БАКД «Праймікс Біонорм К» у період реалізації стресового синдрому чинить позитивний вплив на показники клітинної і гуморальної ланки неспецифічної резистентності у вигляді зростання величини БАСК на $38,2 \%$ (Р $<0,05)$, підвищення ФА на $15,1 \%(\mathrm{P}<0,05)$, ФІ на $36,1 \%(\mathrm{P}<0,05)$ зі зниженням кількості ЦІК на 15,5 \%. Випоювання добавки «Біовір» зумовлює підвищення величини БАСК на $47,3 \%$ ( $>00,01)$ та ЛАСК на $18,7 \%$ ( $<<0,05)$. Застосування добавок дозволяє знизити негативну дію транспортного стресу в організмі качок, підвищити засвоєння поживних речовин корму, на що вказує збільшення маси тіла птиці дослідних груп в середньому на 7,1$10,5 \%(\mathrm{P}<0,05)$ впродовж розвитку адаптаційного синдрому.

Перспективи подальших досліджень бачимо у дослідженні стану імунологічної реактивності організму качок у стресові періоди при включенні в раціон БАКД «Праймікс Біонорм-К» та кормової добавки «Біовір».

\section{References}

Martinez, B., \& Ortiz, R.M. (2017). Thyroid hormone regulation and insulin resistance: Insights from animals naturally adapted to fasting. Physiology. 32(2), 141-151. doi: 10.1152/physiol.00018.2016.

Bolotnikov, I.A., Mihkieva, V.S., \& Olejnik, E.K. (1999). Stress i immunitet $\mathrm{u}$ ptic (in Russian).

Infante, M., Armani, A., Mammi, C., Fabbri, A., \& Caprio, M. (2017). Impact of adrenal steroids on regu- lation of adipose tissue. Comprehensive Physiology. 7(4), 1425-1447. doi: 10.1002/cphy.c160037.

Chen, N.N., Liu, B., Xiong, P.W., Guo, Y., He, J.N., Hou, C.C., Ma, L.X., \& Yu, D.Y. (2018). Safety evaluation of zinc methionine in laying hens: Effects on laying performance, clinical blood parameters, organ development, and histopathology. Poultry Science. 97(4), 1120-1126. doi: 10.3382/ps/pex400.

Gutyj, B., Leskiv, K., Shcherbatyy, A., Pritsak, V., Fedorovych, V., Fedorovych, O., Rusyn, V., \& Kolomiiets, I. (2017). The influence of Metisevit on biochemical and morphological indicators of blood of piglets under nitrate loading. Regulatory Mechanisms in Biosystems. 8(3), 427-432. doi: 10.15421/021766.

Voronina, O.K. (2003). Nadnyrkovi zalozy ptahiv: cytofiziologija ta uchast $\mathrm{u}$ stres-reakcii. Visnyk Kyivskogo universytetu, Biologija. 39(40), 97-100 (in Ukrainian).

Hariv, M.I., \& Gutyj, B.V. (2017). Dynamika fagocytarnoi' aktyvnosti nejtrofiliv u shhuriv za umov oksydacijnogo stresu ta dii' liposomal'nogo preparatu. Biologija tvaryn. 19(1), 119-124. doi: 10.15407/animbiol19.01.119.

Stojanovskij, V.G., Kolomiec, I.A., Kamracka, O.I., \& Kolotnickij, V.A. (2012). Fiziologichnyi stan organizmu kurchat-brojleriv u kritichni vikovi periody pry zastosuvanni imunokoregujuchyh preparativ na tli vakcinacii. Naukovyi visnyk Lvivskogo nacionalnogo universitetu veterinarnoi medycyny ta biotehnologij imeni S.Z. Gzhyckogo, Serija «Veterinarni nauki». 14, 2(53), 236-239 (in Ukrainian).

Stojanovskij, V.G., Kolomiec, I.A., Garmata, L.S., \& Kamracka, O.I. (2018). Zminy morfofunkcional'nogo stanu organiv endokrynnoi ta imunnoi system perepeliv promyslovogo vyroshhuvannja za dii stresu. Fiziologichnyi zhurnal. 64(1), 25-33 (in Ukrainian).

Olubodun, J., Zulkifli, I., Hair-Bejo, M., Kasim, A., \& Soleimani, A.F. (2015). Physiological response of glutamine and glutamic acid supplemented broiler chickens to heat stress. European Poultry Science. 79,1-12. doi: 10.1399/eps.2015.87.

Pavlova, I. (2015). Effect of probiotics on doxycycline disposition in gastro-intestinal tract of poultry. Bulgarian Journal of Veterinary Medicine. 18(3), 248-257. doi: $10.15547 /$ bjvm.908.

Kapustian, A., Cherno, N., Stankevich, G., Kolomiiets, I., Matsjuk, O., Musiy, L., \& Slyvka, I. (2018). Determination of the enzyme destruction rational mode of biomass autolysate of lactic acid bacteria. EasternEuropean Journal of Enterprise Technologies. 1/11 (91), 63-68. doi: 10.15587/1729-4061.2018.120877.

Khariv, M., Gutyj, B., Ohorodnyk, N., Vishchur, O., Khariv, I., Solovodzinska, I., Mudrak, D., Grymak, C., 
\& Bodnar, P. (2017). Activity of the T- and B-system of the cell immunity of animals under conditions of oxidation stress and effects of the liposomal drug. Ukrainian Journal of Ecology. 7(4), 536-541. doi: 10.15421/2017_157.

Khariv, I., Gutyj, B., Hunchak, V., Slobodyuk, N., Vynyarska, A., Sobolta, A., Todoriuk, V., \& Seniv, R. (2017). The influence of brovitatoxide in conjunction with milk thistle fruits on the immune system of turkeys for eimeriozic invasion. Scientific Messenger LNUVMBT named after S.Z. Gzhytskyj, 19(73), 163168. doi:10.15421/nvlvet7334.

Vlizlo, V.V., Fedoruk, R.S., \& Ratich, I.B. (2012). Laboratorni metody doslidzhen u biologii, tvarynnyctvi ta veterynarnij medycyni: dovidnik (in Ukrainian).

Kolomiec, I.A. (2013). Doslidzhennja funkcionuvannja Ti V-lanky imunitetu brojleriv na tli vakcinacii pry zastosuvanni simbiotika «Prajmiks-Bionorm $\mathrm{P}$ » ta rozchinu visokochistogo natriju gipohloritu. Visnik Dnipropetrovskogo derzhavnogo agrarnogo universitetu. 1, 171-172 (in Ukrainian).
Vishhur, O.I., Ogorodnik, N.Z., Mudrak, D.I., Broda, N.A., \& Jackevich, N.A. (2010). Ontogenetichni osoblivosti gematologichnogo profilju krovi ta pokaznikiv fagocitozu u muskusnih kachok ta kachokbrojleriv. Naukovo-tehnichnij bjuleten Institutu biologii tvarin NAANU ta DNDKI veterinarnih preparativ ta kormovih dobavok. 11(1), 246-249 (in Ukrainian).

Mohammed, A.A., Jacobs, J.A., Murugesan, G.R., \& Cheng, H.W. (2018). Effect of dietary synbiotic supplement on behavioral patterns and growth performance of broiler chickens reared under heat stress. Poultry Science. 97(4), 1101-1108. doi: $10.3382 / \mathrm{ps} / \mathrm{pex} 421$.

Wójcik, E., \& Smalec, E. (2017). Constitutive heterochromatin in chromosomes of duck hybrids and goose hybrids. Poultry Science. 96(1), 18-26. doi: $10.3382 / \mathrm{ps} /$ pew318.

Gaevska, M.Ju. (2000). Cirkuljujuchi imunni kompleksy za umov normy ta patologii. Visnyk naukovyh doslidzhen. (4), 37-40 (in Ukrainian). 